\title{
KONSISTENSI PASAL 284 KUHP TERHADAP UNDANG-UNDANG DASAR NEGARA REPUBLIK INDONESIA TAHUN 1945
}

\author{
Any Ismayawati \\ Sekolah Tinggi Agama Islam Negeri (STAIN) Kudus \\ Jl. Conge Ngembal Rejo No.51, Ngembalrejo, Bae, Kabupaten Kudus \\ Email : any.ismayawati@yahoo.com
}

\begin{abstract}
Adultery issue has been regulated in Article 284 of the Indonesian Criminal Code. However, in its implementation, vigilantism is more widely used by the community in response to the suit. In short it can be said that Article 284 of the Criminal Code is not effective in combating the crime of adultery. Article 284 of the Criminal Code, both legally and philosophically opposed to the values contained in Article 29 Paragraph (1) of Indonesian Constitution. In juridical, adultery prohibition in the norms of religion in Indonesia not only in people who already tied a marital relationship. In philosophy, the prohibition of adultery in the norms of religion in Indonesia is not only to provide protection to the institution of marriage, but also protect the sanctity of sexual relations, nasab, individual honour and even social honour. It can be said that the prohibition of adultery in religious norms is a form of protection against social honor as well as protection against "social values of sexual morality".
\end{abstract}

Keywords: Adultery, vigilantism, institution of marriage, Religious Norms.

\begin{abstract}
Abstrak
Perkara perzinahan telah diatur di dalam KUHP Pasal 284. Akan tetapi, Dalam implementasinya, tindakan main hakim sendiri lebih banyak digunakan oleh masyarakat dalam menyelesaikan perkara tersebut. Secara singkat dapat dikatakan bahwa Pasal 284 KUHP tidak efektif dalam penanggulangan tindak pidana perzinahan. Secara yuridis dan filosofis Pasal 284 KUHP bertentangan dengan nilai yang terkandung di dalam Pasal 29 ayat (1) UUD 1945. Secara Yuridis, larangan zina dalam norma-norma agama di Indonesia tidak hanya pada orang yang sudah terikat tali perkawinan saja. secara filosofi, larangan zina dalam norma-norma agama di Indonesia tidak hanya memberi perlindungan pada lembaga perkawinan, melainkan juga melindungi kesucian hubungan seksual, nasab, kehormatan individu maupun kehormatan sosial. Dapat dikatakan bahwa pelarangan zina dalam nomanorma agama merupakan bentuk perlindungan terhadap kehormatan sosial serta perlindungan terhadap "social values of sexual morality".
\end{abstract}

\section{Kata Kunci: perzinahan, main hakim sendiri, lembaga perkawinan, norma agama.}

\section{A. Pendahuluan}

Keberadaan Mahkamah Konstitusi (MK) pada lembaga yudikatif Indonesia membawa angin segar pada upaya penyelarasan perundang-undangan dengan konstitusi yang dalam hal 
ini adalah Undang-undang Dasar Negara Republik Indonesia Tahun 1945, karena salah satu kewenangan MK adalah membatalkan peraturan perundang-undangan yang bertentangan dengan konstitusi. Salah satu kewenangan MK tersebut merupakan perwujudan dari stufenbau theori yang dikemukakan oleh Hans Kelsen, bahwa suatu peraturan harus berdasarkan pada peraturan di atasnya, artinya peraturan yang ada dibawah tidak boleh bertentangan dengan peraturan di atasnya. Implikasi dari teori tersebut adalah peraturan perundangan yang bertentangan dengan peraturan di atasnya harus dibatalkan keberlakukannya. Pembatalan beberapa peraturan perundang-undangan yang dilakukan oleh MK juga merupakan salah satu upaya untuk mewujudkan kepastian dan unifikasi hukum.

Dalam tataran praksis terdapat beberapa perundang-undangan yang diadopsi dari jaman pemerintahan kolonial. Perundang-undangan yang sudah ada pada pemerintahan kolonial sudah barang pasti dibentuk sebelum ditetapkannya UUD Negara Republik Indonesia Tahun 1945 (UUD 1945) sebagai konstitusi Negara Republik Indonesia. Bertolak pada hal tersebut perlu kiranya untuk dikaji konsistensinya dengan UUD 1945. Beberapa perundang-undangan yang diadopsi dari pemerintahan kolonial diantaranya adalah Kitab Undang-undang Hukum Pidana (KUHP). KUHP yang berlaku pada saat ini merupakan induk hukum pidana tertulis. Pada kesempatan ini akan dikaji sejauh mana konsistensi Pasal 284 KUHP tentang pelarangan tindak perzinahan terhadap UUD NRI Tahun 1945.

Dasar pertimbangan pengkajian Pasal 284 KUHP adalah karena seringnya terjadi main hakim sendiri oleh masyarakat apabila terjadi perzinahan. Terjadinya main hakim dalam penyelesaian tindak perzinahan perlu dipertanyakan, karena payung hukum sudah jelas ada akan tetapi masyarakat jarang menggunakan. Masyarakat lebih sering menggunakan nilainilai yang hidup dalam masyarakat dalam menyelesaikan tindak perzinahan. Tindakan masyarakat tersebut memunculkan permasalahan karena main hakim sendiri merupakan faktor kriminogen terhadap munculnya tindak pidana yang lain. Di samping sebagai faktor kriminogen, tindakan main hakim sendiri juga menimbulkan keresahan masyarakat karena tidak adanya kepastian hukum, bahkan berujung terjadinya kesewenang-wenangan pada pihak-pihak tertentu. Secara singkat dapat dikatakan bahwa Pasal 284 KUHP tidak efektif dalam penanggulangan tindak perzinahan.

\section{B. Sejarah Berlakunya Pasal 284 KUHP Sebagai Hukum Positif}

Sebelum mengkaji lebih jauh Pasal 284 KUHP, perlu kiranya untuk diketahui bagaimana proses digunakannya pasal tersebut sebagai hukum positif di Indonesia. Pasal 284 merupakan bagian dari KUHP yang berasal dari Belanda. KUHP yang berasal dari WvSvNI ini merupakan sebuah Titah Raja yang ditetapkan pada tanggal 15 Oktober 1915 dan mulai berlaku tanggal 1 Januari 1918. Berarti KUHP dibuat beberapa abad yang lalu digunakan untuk mengatur masyarakat pada saat itu. Artinya KUHP ini dibentuk untuk masayarakat Belanda pada masa itu yang sudah barang tentu nilai-nilai yang mendasari dan setting social sangat berbeda jauh dengan bangsa Indonesia pada masa kini. Oleh sebab itu permasalahan 
menjadi berbeda ketika bangsa ini sudah merdeka selama 70 tahun, hukum yang digunakan masih hukum yang berasal dari pemerintah kolonial.

Menggunakan KUHP sebagai induk hukum pidana berarti mempertahankan transplantasi hukum Belanda pada masyarakat Indonesia. Hal tersebut merupakan kebijakan yang tidak tepat, karena kosmologi bangsa Belanda tidak sama dengan kosmologi bangsa Indonesia. Sebagaimana yang dikatakan Robert B. Seidman', bahwa hukum tidak dapat begitu saja ditransplantasikan dari bangsa satu ke bangsa yang lain karena masing-masing bangsa mempunyai kosmologi yang berbeda. KUHP yang berasal dari Belanda tersebut tidak mempunya akar pada basis sosial bangsa Indonesia, atau dengan kata lain tidak ada hubungan yang erat antara Pasal 284 KUHP dengan masyarakat Indonesia, maka sangat tidak tepat apabila KUHP khususnya Pasal 284 KUHP ditransplantasikan ke Indonesia.

Diungkapkan oleh Barda Nawawi Arief, bahwa ketiadaan konsistensi antara peraturan dengan kenyataan di dalam masyarakat akan menjadi faktor kriminogen. Demikian pula halnya penggunaan Pasal 284 KUHP menjadi kriminogen, karena esensi pasal tersebut jauh dari perasaan dan nilai-nilai yang hidup di dalam masyarakat Indonesia. ${ }^{2}$ Hal tersebut menjadikan semakin besar ketidakpercayaan pada efektivitas penggunaan Pasal 284 KUHP dalam menanggulangi tindak perzinahan.

Digunakannya KUHP (yang dalam hal ini adalah Pasal 284) oleh bangsa Indonesia, berdasarkan pada pertimbangan-pertimbangan politik pada masa itu. Politik hukum pada awal pasca kemerdekaan Indonesia tidak menghendaki terjadinya kekosongan hukum, maka penggunaan undang-undang yang diadopsi dari Belanda merupakan suatu kebijakan yang dapat diterima. Hukum kolonial tersebut diadopsi dengan berdasar pada Pasal 2 Aturan Peralihan UUD 1945 sebagai "pasal jembatan" dalam menghadapi masa transisi yang belum memungkinkan dibentuknya undang-undang baru. Melalui Undang-undang Nomor 1 tahun 1946, KUHP Belanda (Wetboek van Strafrecht voor Nederlandsch Indie) diganti menjadi Wetboek Van Strafrecht (WVS) yang diterjemahkan dalam bahasa Indonesia menjadi Kitab Undang-undang Hukum Pidana (KUHP). Dalam Pasal V Undang-undang Nomor 1 tahun 1946 tentang Peraturan Hukum Pidana diatur kriteria atau kisi-kisi tentang pasal-pasal yang tidak dapat diberlakukan. Tidak semua pasal yang ada dalam KUHP Belanda diberlakukan. Adapun kriteria yang tertuang dalam Pasal V adalah: yang seluruhnya atau sebagian tidak dapat dijalankan, bertentangan dengan kedudukan RI sebagai negara merdeka, dan tidak mempunyai arti lagi ${ }^{3}$. Berdasar bunyi pasal tersebut tidak terdapat ketentuan yang mengharuskan adanya konsistensi terhadap UUD 1945.

Barangkali dengan memahami politik hukum pada masa itu akan didapat penjelasan mengapa Pasal 284 KUHP masih tetap diberlakukan. Politik hukum merupakan alat atau

\footnotetext{
Suteki, Integrasi Hukum dan Masyarakat, Semarang, Pustaka Magister 2007, hlm.1

2 Barda Nawawi Arief, Beberapa Aspek Pengembangan Ilmu Hukum Pidana (Menyongsong Generasi Baru Hukum Pidana Indonesia, Pidato Pengukuhan Guru Besar Fakultas Hukum Undip, Semarang, 25 Juni 1994, hlm.362

3 Barda Nawawi Arief, Reformasi Sistem Peradilan (Sistem Penegakan Hukum) di Indonesia, Badan Penerbit Universitas Diponegara, Semarang, 2011, hlm. 12.
} 
sebagai sarana dan langkah yang dapat digunakan pemerintah untuk menciptakan sistem hukum nasional dalam upaya mencapai cita-cita bangsa ${ }^{4}$. Moh. Mahfud MD mengatakan jika hukum diartikan sebagai alat untuk meraih cita-cita dan mencapai tujuan, maka politik hukum diartikan sebagai arah yang harus ditempuh dalam pembuatan dan penegakan hukum guna mencapai cita-cita dan tujuan bangsa atau dengan kata lain politik hukum adalah upaya menjadikan hukum sebagai proses pencapaian cita dan tujuan. ${ }^{5}$ Masih menurut Moh. Mahfud MD $^{6}$, politik hukum mencakup proses pembuatan dan pelaksanaan hukum yang dapat menunjukkan sifat dan ke arah mana hukum akan dibangun dan ditegakkan.

Mengacu pada pengertian politik hukum tersebut maka dapat diketahui bahwa kehendak penguasa memberlakukan KUHP dengan melalui Undang-Undang Nomor 1 Tahun 1946 (yang dalam hal ini adalah Pasal 284 KUHP) merupakan salah satu bentuk upaya pembaharuan hukum pidana yang semula berdasarkan WvSvNI disesuaikan dengan kondisi bangsa Indonesia menjadi WvS yang diterjemahkan KUHP. Akan tetapi perubahan yang dilakukan oleh undang-undang tersebut tidak menyentuh jiwa/roh dari peraturan itu sendiri, jadi hanya bersifat penyesuaian yang tambal sulam. Seharusnya politik hukum tentang perubahan hukum pidana tidak hanya sekedar "penyesuaian" saja, karena melalui kemerdekaan Indonesia yang diproklamasikan pada tanggal 17 Agustus 1945, serta dengan UUD 1945 sebagai hukum dasarnya, menuntut adanya pembaharuan atau penggantian atas hukum-hukum peninggalan penjajah.

\section{Konsistensi Yuridis Pasal 284 KUHP terhadap Pasal 29 ayat (1) UUD NRI Tahun 1945}

Dalam UUD 1945 Pasal 29 ayat (1) menyebutkan bahwa "Negara berdasar atas Ketuhanan Yang Maha Esa". Bunyi pasal tersebut mengandung makna bahwa nilai-nilai agama menjadi dasar atau pedoman dalam penyelenggaraan negara, termasuk dalam hal pembangunan hukum. Dapat diartikan pula bahwa setiap peraturan perundangan yang ada di Indonesia tidak boleh bertentangan dengan nilai-nilai tuntunan Tuhan (norma-norma agama).

Dalam konteks memperjelas konsistensi dari content Pasal 284 KUHP terhadap Pasal 29 ayat (1) UUD 1945, maka perlu kiranya diurai bunyi Pasal 284 KUHP. Adapun bunyi pasal tersebut adalah sebagai berikut :

(1) Diancam dengan pidana penjara paling lama sembilan bulan:

4 Sunaryati Hartono, Politik Hukum Menuju Sistem Hukum Nasional, Alumni, Bandung, 1991, hlm. 1

5 Mahfud MD, Membangun Politik Hukum Menegakkan Konstitusi, Pustaka LP3ES Indonesia, Jakarta, 2006, hlm. 31

6 Moh.Mahfud Md, Politik Hukum di Indonesia, Rajawali Pers, Jakarta, 2009, hlm.17 Berdasarkan pendapat Abdul Hakim Garuda Nusantara bahwa Politik Hukum sebagai Legal Policy yang yang akan dan telah dilaksanakan secara nasional oleh pemerintah Indonesia yang meliputi : pertama, pembangunan hukum yang berintikan pembuatan dan pembaharuan terhadap materi-materi hukum agar dapat sesuai dengan kebutuhan; kedua, pelaksanaan ketentuan hukum yang telah ada termasuk penegasan fungsi lembaga dan pembinaan para penegak hukum 
1.a. Seorang pria yang telah kawin yang melakukan mukah (overspel) padahal diketahui bahwa pasal $27 \mathrm{BW}$ berlaku baginya;

b. Seorang wanita yang telah kawin yang melakukan mukah.

2.a. Seorang pria yang turut serta melakukan perbuatan itu, padahal diketahuinya bahwa yang turut bersalah telah kawin.

b. Seorang wanita yang telah kawin yang turut serta melakukan perbuatan itu, padahal diketahui olehnya bahwa yang turut bersalah telah kawin dan pasal 27 BW berlaku baginya.

(2) Tidak dilakukan penuntutan melainkan atas pengaduan suami/isteri yang tercemar, dan bilamana bagi mereka berlaku pasal $27 \mathrm{BW}$, dalam tenggang waktu tiga bulan diikuti dengan permintaan bercerai atau pidah meja atau ranjang karena alasan itu juga.

(3) Terhadap pengaduan ini tidak berlaku pasal 72, pasal 73, pasal 75 KUHP

(4) Pengaduan dapat ditarik kembali selama pemeriksaan dalam sidang pengadilan belum dimulai.

(5) Jika bagi suami isteri berlaku pasal $27 \mathrm{BW}$, pengaduan tidak diindahkan selama perkawinan belum diputuskan karena perceraian atau sebelum putusan yang menyatakan pisah meja atau ranjang menjadi tetap.

Hal yang perlu dikaji dalam pasal ini adalah batasan zina yang dapat dikenai sanksi, bentuk sanksi zina dan jenis delik. Dalam pasal ini disebutkan bahwa dapat dikenai sanksi apabila pelaku perzinahan dilakukan oleh orang-orang - yang salah satu atau kedua-duanya terikat tali perkawinan, sehingga apabila ada laki-laki dan perempuan yang masing-masing tidak terikat tali perkawinan melakukan perzinahan, maka tidak dapat dikenai sanksi atau tidak dapat dipidana dengan kata lain perbuatan tersebut bukan delik perzinahan. Adapun sanksi yang dapat dijatuhkan maksimal hanya 9 sembilan bulan pidana penjara.

Melihat bentuk sanksi tersebut dapat dimaknai bahwa pasal ini hanya memperhatikan sisi pelaku saja tanpa memperhitungkan kepentingan korban. Sedangkan kerugian yang diderita korban tidak hanya kerugian matriil saja melainkan juga kerugian moril yang tidak ringan. Di samping itu penuntutan dapat dilakukan apaabila ada pengaduan dari suami atau istri dari pelaku perzinahan. Artinya, apabila tidak ada pengaduan dari pihak suami atau istri pelaku tidak dapat dilakukan penuntutan sehingga sanksi tidak dapat dikenakan.

Bunyi ketentuan tentang keharusan adanya pengaduan dari pihak suami atau istri pelaku juga terkandung arti bahwa pihak lain selain suami atau istri pelaku tidak dapat melakukan pengaduan. Penyelesaian delik dalam pasal ini tidak harus sampai ke persidangan karena pengaduan dapat ditarik kembali apabila proses belum sampai ke persidangan. Hal tersebut menunjukkan bahwa Pasal 284 KUHP adalah delik aduan absolut. Dijadikannya delik perzinahan sebagai delik aduan absolut merupakan faktor yang mempengaruhi efektivitas penegakan pasal tersebut. Pembatasan pihak yang dapat mengadukan hanya suami atau istri yang tercemarkan menunjukkan bahwa pasal ini menganggap korban tindak perzinahan hanya suami atau istri pelaku. 
Persyaratan adanya ikatan perkawinan untuk dapat dijatuhkannya sanksi pada pelaku perzinahan dalam Pasal 284 KUHP tersebut dapat dijelaskan dengan memahami nilai-nilai perkawinan orang Belanda serta hubungan antara agama dan negara di Belanda. Bagi orang Belanda perkawinan adalah urusan atau kepentingan antar individu, tidak melibatkan keluarga, apalagi masyarakat. sehingga persetubuhan yang dilakukan oleh orang yang belum ada ikatan perkawinan merupakan urusan masing-masing individu, artinya negara tidak perlu campur tangan untuk menjatuhkan sanksi pada perbuatan tersebut. Sedangkan bagi yang sudah terikat perkawinan, negara ikut bertanggung jawab karena sudah ada lembaga yang dirugikan, dan lembaga tersebut sudah dicatatkan dalam negara.

Syarat adanya ikatan perkawinan untuk dapat dijatuhkan sanksi sangat terkait dengan bentuk hubungan antara agama dan negara bangsa Belanda yang menganut paradigma sekularistik. Paham ini berpendapat bahwa hukum positif yang berlaku adalah hukum yang berasal dari kesepakatan manusia melalui social contract yang tidak terikat sama sekali dengan hukum agama ${ }^{7}$. Oleh sebab itu wajar apabila hukum Belanda tidak berdasarkan pada norma-norma agama, termasuk aturan tentang delik perzinahan.

Bertolak pada penjelasan di atas maka dapat dikatakan bahwa Pasal 284 KUHP secara yuridis bertentangan dengan Pasal 29 ayat (1) UUD 1945, karena bunyi pasal ini mengandung arti bahwa negara dijalankan berdasarkan atas nilai-nilai ketuhanan atau hukum yang ada harus berbasis pada norma-norma agama. Sedangkan isi Pasal 284 KUHP sangat jauh bahkan dapat dikatakan bertentangan dengan norma-norma agama yang ada di Indonesia.

Ketidakkonsistenan Pasal 284 KUHP dengan Pasal 29 ayat (1) UUD 1945 secara jelas dapat deketahui dengan melihat aturan pelarangan zina dalam norma-norma agama. Dalam hukum Islam bentuk zina dibagi dua, Pertama, yaitu zina ghoiru muhson yang artinya persetubuhan antara orang dewasa yang belum kawin (fornication). Kedua, yaitu zina muhson yang artinya persetubuhan yang dilakukan oleh laki-laki dengan perempuan yang bukan suami istri dan salah satu atau keduanya sudah terikat dalam perkawinan dengan suami/istri lain $^{8}$ (adultery). Dari pembagian jenis zina tersebut menunjukkan bahwa pada dasarnya hukum Islam melarang zina, baik yang terikat perkawinan maupun tidak.

Hukum Islam tidak hanya melarang zina, perbuatan yang mendekati zina juga dilarang, artinya perbuatan-perbuatan yang mendorong atau yang menyebabkan seseorang melakukan zina juga dilarang. ${ }^{9}$ Sebagaimana bunyi Qur'an surat Al-Isra' : 32 “dan janganlah kamu mendekati zina; sesungguhnya zina itu adalah suatu perbuatan yang keji. Dan suatu jalan yang buruk".

Sedangkan sanksi bagi pelaku zina menurut hukum Islam diatur dalam Qur'an Surat AnNur ayat 2, yaitu:

"Perempuan dan laki-laki yang berzina, deralah kedua-duanya, masing-masing seratus kali dera. Janganlah sayang kepada keduanya dalam menjalankan hukum agama Allah,

\footnotetext{
7 A. Ubaidillah dan Abdul Rozak, Demokrasi, Hak Asasi Manusia dan Masyarakat Madani, ICCE UIN Syarif Hidayatullah Jakarta, Jakarta, 2006, hlm.40.

8 Oemar Seno Adji, Hukum (Acara) Pidana dalam Prospeksi, cet. Ke-2, Erlangga, Jakarta, 1976, hlm. 49-51.

9 Al-Qur'an, Surat Al-Isra': 32.
} 
kalau kamu betul-betul beriman kepada Allah dan hari kemudian; dan hendaknya hukuman bagi keduanya itu disaksikan oleh sekumpulan orang yang beriman".

Dalam hadist nabi Muhammad SAW dijelaskan bahwa hukuman rajam bagi pezina yang pernah kawin, baik laki-laki maupun perempuan apabila terdapat bukti yang nyata dan/dia telah hamil atau pengakuannya sendiri. Sedangkan pezina yang belum pernah kawin Rasulullah menjatuhkan hukuman cambuk sebanyak 100 kali dan diasingkan selama setahun. ${ }^{10}$ Berdasarkan bentuk sanksi tersebut dapat dikatakan bahwa disamping hukuman fisik, Islam juga memberikan sanksi moral maupun sosial yaitu dengan diasingkannya pelaku. Di samping sanksi sosial yang berupa pengasingan, juga dikenal sanksi berupa diumumkannya aibnya, diasingkan (Taghrib), tidak boleh dinikahi dan ditolak persaksiannya $^{11}$.

Agama Kristen Protestan maupun Katholik juga mengartikan zina secara luas, artinya zina tidak hanya dimaknai sebagai hubungan suami istri di luar perkawinan yang sah, akan tetapi termasuk dalam perbuatan zina antara lain seseorang yang memandang perempuan dan tertarik maka oleh Yesus dikatakan sudah berbuat zina di dalam hatinya, dan menurut beberapa tafsir Alkitab, berkeinginan untuk berbuat zina sudah sama sifatnya dengan berzina $^{12}$. Sebagaimana dalam Kitab/Injil yang tertuang dalam Matius 5: 28-29, yaitu :

"Setiap orang yang memandang perempuan serta menginginkannya, sudah berzina dengan dia di dalam hatinya. Maka jika matamu yang kanan menyesatkan engkau, cungkillah dan buanglah itu, karena lebih baik bagimu jika satu dari anggota tubuhmu binasa, dari pada tubuhmu dengan utuh dicampakkan ke dalam neraka".

Batasan zina menurut agama Kristen Protestan dan Katholik tidak hanya pada orang yang terikat tali perkawinan. Hal tersebut dapat dilihat di dalam agama ini, bahwa berkeinginan zina dipersamakan dengan berbuat zina, sedangkan yang dapat mempunyai keinginan zina dapat terjadi pada orang yang belum terikat tali perkawinan.

Dalam Alkitab sanksi perbuatan zina antara lain diatur dalam Imamat 20:10, yaitu: "Bila seorang laki-laki berzina dengan isteri orang lain, yakni berzina dengan isteri sesamanya manusia, pastilah keduanya dihukum mati, baik laki-laki maupun perempuan yang berzina itu." (Perjanjian Lama, hlm. 131). Adapun dalam Amsal 6:32-33 disebutkan: "siapa melakukan zina tidak berakal budi; orang yang berbuat demikian merusak diri. Siksa dan cemooh diperolehnya, malunya tidak terhapuskan". (Perjanjian Lama,hlm. 686). Dari ketentuan dalam Alkitab tersebut dapat diketahui bahwa sanksi yang diberikan kepada pelaku zina tidak hanya berupa pidana mati, akan tetapi ada bentuk sanksi lain yaitu sanksi sosial yang berupa pencemoohan dan permaluan. Bentuk sanksi lain terhadap perbuatan zina juga dapat dilihat dalam Alkitab, Perjanjian Baru, yang antara lain memuat: "Barangsiapa diantara

${ }^{10}$ Berdasarkan kesimpulan Zainuddin dalam Hukum Pidana Islam, Sinar Grafika, Jakarta, 2007, hlm. 47. Beliau menyimpulkn dari beberapa hadist Nabi dalam menyelesaikan kasus-kasus zina yang terjadi pada umat nabi Muhammad SAW.

11 Dalam Neng Djubaedah, Perzinaan dalam Peraturan Perundang-undangan di Indonesia Ditinjau dari Hukum Islam, Kencana Prenada Media Group, Jakarta, 2010, hlm. 74-75

12 <http://id.wikipedia.org/wiki/Pelacuran_menurut_agama>, diakses pada hari Sabtu 21-Juli . 2012, diperkuat dengan Hasil wawancara dengan Bapak Andreas Ketua Persatuan Gereja Indonesia 
kamu tidak berdosa, hendaklah ia pertama melemparkan batu kepada perempuan zina itu". ${ }^{3}$ Ketentuan yang terakhir ini menunjukkan bahwa perbuatan zina bukan sebagai delik aduan.

Dalam agama Hindu, khususnya bagi pemeluk Hindu di Bali, masalah zina diuraikan dalam Trikaya Parisudha tentang Kayika, yang disebut: "tan paradara". Pengertian tan paradara ini diartikan luas sebagai menggoda, bersentuhan seks, berhubungan seks, bahkan menghayalkan seks dengan wanita/ lelaki lain yang bukan istri/ suaminya yang sah. ${ }^{14}$ Dalam agama Hindu, untuk bisa melakukan hubungan seks hanya bisa dilakukan setelah seseorang melangsungkan proses pawiwahan (perkawinan) dengan aturan yang telah ditentukan. Bertolak pada hal tersebut maka bagi umat Hindu batasan zina tidak hanya pada oang yang terikat tali perkawinan saja, melainkan siapapun yang melakukan hubungan seksual tanpa melangsungkan proses pawiwahan adalah zina.

Zina dalam agama Hindu disebut Samgrahana Gamana. Ketentuan etika atau tata susila dalam agama Hindu diatur dalam kitab Manawa Dharmasastra, Gautama Smerti, Parasara Dharmasastra, Slokantara, Kamasutra, dan sebagainya, yang kesemuanya bersumber pada Veda Sruti. Berdasarkan ketentuan yang ada dalam kitab tersebut, semua perbuatan yang menyimpang dari tata susila atau etika akan memperoleh sanksi, baik sanksi moral maupun sanksi hukum.

Dalam agama Budha perbuatan zina termasuk dalam pengelompokan "Sepuluh Kamma Buruk". Disamping itu, perbuatan zina termasuk pula dalam pengelompokan perbuatan buruk yang dinamakan Kammakilesa. Ada empat macam perbuatan yang masuk dalam Kammakilesa, salah satunya adalah Kamesu-Micchacara, yaitu kelakuan salah berkenaan dengan seks. Dari pengelompokan perbuatan buruk tersebut dibuat "Lima Sila" atau peraturan kemoralan, yang salah satunya Kamesu-Micchacara Veramani yang artinya agar menahan diri dari kelakuan seks yang salah ${ }^{15}$. Agama Buddha melarang perzinahan, meskipun tidak dicantumkan sanksi bagi yang melanggar. Dalam agama Buddha terdapat keyakinan bahwa apabila orang tidak bertingkah laku sebagaimana yang diatur, maka orang tersebut akan menerima Dukkha atau penderitaan ${ }^{16}$.

Berdasar pada beberapa pengertian tentang zina dari berbagai agama yang ada di Indonesia menunjuk pada adanya suatu perbuatan yang berupa hubungan persetubuhan yang tidak dalam perkawinan yang sah, baik sah menurut agama atau menurut negara. Adanya larangan terhadap persetubuhan di luar perkawinan yang sah menunjukkan bahwa ada suatu upaya untuk melindungi lembaga perkawinan. Tingkatan perlindungan terhadap lembaga perkawinan tersebut tentunya sesuai dengan makna keberadaan perkawinan dalam masyarakat

${ }^{13}$ Leden Marpaung, Kejahatan Terhadap Kesusilaan dan Masalah Prevensinya, Sinar Grafika, Jakarta, 2008, hlm.5

14 Hasil wawancara dengan bapak I Nengah Dhana Ketua Hindu Dharma Indonesia

15 Hasil wawancara dengan bapak Suhadi Ketua Budha Dharma Indonesia diperkuat yang tertuang dalam buku H.R.H.The Late Supreme Ptriarch, Prince Vajirananavarorasa, Gihi Patipatti, alih Bahasa : Bhikkhu Jeto, Vuhara Hettu Ratna Lokha, Pati, 1993, hlm. 1-8.

16 Pandita S. Widyadharma, Inti Sari Agama Buddha, Yayasan Dana Pendidikan Buddhis Nalanda, Jakarta, 1983, hlm. 10. 
itu sendiri. Sebagaimana yang dikemukakan oleh Barda Nawawi Arief ${ }^{17}$ bahwa perzinahan merupakan salah satu delik kesusilaan yang erat kaitannya dengan kesucian lembaga perkawinan, sehingga masalah sentralnya terletak pada pandangan masyarakat mengenai kesusilaan dan kesucian lembaga perkawinan.

Mendasarkan pada aturan zina yang ada dalam norma-norma agama secara umum dapat dikatakan bahwa zina yang dilarang meliputi perzinahan yang dilakukan orang yang terikat tali p0erkawinan maupun yang tidak sama sekali. Sanksi terhadap tindak perzinahan menurut norma agama ada yang berupa pidana mati, pidana rajam, pidana cambuk, pidana pengasingan dan pidana permaluan atau sanksi soaia. Melihat beberapa bentuk jenis sanksi tersebut dapat dikatakan bahwa sanksi perzinahan tidak cukup hanya pidana penjara atau pidana pengasingan saja. Adapun jenis delik untuk tindak perzinahan menurut norma agama adalah delik biasa bukan delik aduan.

Berdasarkan pada uraian di atas maka dapat dikatakan bahwa Pasal 284 KUHP sama sekali tidak konsisten atau bertentangan dengan UUD 1945, khususnya terhadap Pasal 29 ayat (1). Oleh sebab itu pembatalan atau tidak diberlakukannya Pasal 284 KUHP merupakan hal yang sangat dimungkinkan. Sebagaimana yang dikatakan oleh Hazairin" "Dalam negara Republik Indonesia tidak boleh terjadi atau berlaku sesuatu yang bertentangan dengan kaidahkaidah Islam bagi umat Islam, atau kaidah-kaidah Kristiani bagi umat Kristiani/ Katholik atau bertentangan dengan kaidah-kaidah agama Hindu Bali bagi orang-orang Hindu Bali atau yang bertentangan dengan kesusilaan agama Budha bagi orang-orang Budha". Oleh sebab itu dalam menjalankan kehidupan berbangsa, bernegara dan bermasyarakat termasuk di dalamnya dalam berhukum tidak boleh bertentangan dengan norma-norma agama yang diakui di Indonesia.

\section{Konsistensi filosofis Pasal 284 KUHP terhadap Pasal 29 ayat (1) UUD 1945}

Pelarangan zina dalam Pasal 284 KUHP yang hanya membatasi pada perzinahan yang dilakukan oleh orang yang terikat tali perkawinan menunjukkan bahwa pasal tersebut dijiwai paham individualistik-liberalistik. Adapun nilai yang hendak dilindungi hanyalah lembaga perkawinan. Sedangkan pelarangan zina dalam masyarakat Indonesia dilandasi nilai religius dan komunal. Nilai yang hendak dilindungi disamping lembaga perkawinan, juga melindungi kesucian hubungan seksual, nasab, kehormatan, hak milik dan kesehatan.

Dijadikannya delik aduan absolut Pasal 284 KUHP menandakan esensi nilai yang sangat berbeda antara Belanda dan Indonesia dalam memandang suatu perkawinan. Paham bangsa Belanda yang individualistik, mempengaruhi cara pandang masyarakat tentang perkawinan. Perkawinan hanya dipahami sebagai ikatan antara individu yang satu dengan individu yang satunya. Sedangkan bangsa Indonesia yang bersifat komunal kolektif memandang suatu perkawinan tidak sekedar ikatan antar individu tetapi merupakan sebuah ikatan antar

17 Barda Nawawi Arief, Bunga Rampai Kebijakan Hukum Pidana, Citra Aditya, Bandung, 1996, hlm. 279-285.

${ }^{18}$ Hazairin, Demokrasi Pancasila, Bina Aksara, Jakarta, 1985, hlm. 34. 
keluaraga yang menikah, bahkan ikatan antara masyarakat atau ikatan kekerabatan dimana kedua belah pihak bertempat tinggal. Perbedaan pandang dalam melihat perkawinan ini mengakibatkan juga perbedaan dalam memandang kerugian yang ditimbulkan oleh perzinahan. Hal ini yang menjadikan dasar pemikiran dijadikannya delik aduan pada Pasal 284, karena konsep dalam delik ini menganggap bahwa hanya suami/istri yang pasangannya melakukan zina saja yang dirugikan. Sedangkan di Indonesia apabila terjadi perzinahan bagi orang yang telah terikat tali perkawainan maka keluarga atau masyarakat dari masing-masing pihak ikut dirugikan dan terlukai rasa keadilan dan kehormatannya. Sedangkan bagi yang belum terikat tali perkawinan pihak yang dirugikan adalah orang tua dan keluarganya.

Dalam agama Islam, pernikahan merupakan ikatan suci (mistaqan ghalidan) ${ }^{19}$, oleh sebab itu dalam melindungi kesucian perkawinan di dalam agama Islam diatur rukun perkawinan. Apabila rukun perkawinan tidak terpenuhi maka perkawinan tidak sah. Agama Islam mendudukkan perkawinan sebagai tulang punggung kehidupan berkeluarga. Sedangkan keluarga adalah fondasi masyarakat dan merupakan salah satu bentuk ibadah bagi umat muslim. Berkaitan dengan kesucian perkawinan, maka dalam masyarakat muslim pemilihan pasangan hidup melibatkan seluruh keluarga. Perkawinan dalam Islam tidak hanya ikatan antara individu melainkan ikatan antar keluarga besar.

Dalam agama Kristen Protestan perkawinan adalah peristiwa penting yang melibatkan gereja. Dalam agama ini perkawinan adalah suatu lembaga yang suci karena ikatan dari dua orang yang dipersatukan oleh Tuhan. Perkawinan dipandang sebagai kesetiakawanan bertiga antara suami, istri di hadapan Allah. Perkawinan itu suci, dimana seorang pria dan seorang wanita membentuk rumah tangga karena dipersatukan oleh Allah. Dengan perkawinan mereka bukan lagi dua, melainkan satu. ${ }^{20}$

Dalam agama Katholik pandangan tentang perkawinan sama dengan agama Kristen Protestan, bahkan aturannya lebih ketat karena dalam agama Katholik tidak memperbolehkan perceraian, karena menurut agama Katholik perkawinan merupakan disatukannya dua manusia oleh Tuhan, sehingga yang boleh memisahkan hanya Tuhan. Dalam agama Katholik perkawinan adalah persatuan seumur hidup, yang diikat oleh perjanjian, antara seorang pria dan seorang wanita. Melalui perkawinan mereka menjadi suami-istri, berbagi kehidupan secara utuh, saling mengembangkan diri secara penuh dan dalam cinta melahirkan dan mendidik anak-anak (Gaudium et Spes 47-52). ${ }^{21}$

Dalam agama Hindu perkawinan bermakna sebagai tanda dimulainya status "berumah tangga" dan upacara ini merupakan samskara yang ke-13. Umat Hindu Ortodoks tidak mengijinkan perceraian apa pun alasannya. ${ }^{22}$ Kitab suci Veda dalam Agveda X.85.23 mengamanatkan makna perkawinan sebagai penyatuan suami istri yang tidak dapat

\footnotetext{
19 Abu Rohmad, Menjaga Etika dan Norma Perkawinan, dalam Suara Merdeka, Selasa 4 Desember 2012, hlm.6

${ }^{20}$ Makna Perkawinan dalam Berbagai Agama, <http://pormadi.wordpress.com/2008/05/10/makna-perkawinandalam-berbagai-agama/> diunduh pada hari Senin tannggal 25 November 2013

21 Ibid

22 Ibid
} 
dipisahkan dan mampu melahirkan putra suputra yang dapat memberikan dan mewujudkan kebahagiaan lahir dan bathin. Dalam Ågveda VI. 15. 19 diamanatkan bahwa perkawinan adalah hubungan suami istri yang abadi. Sedangkan dalam Ågveda X. 85. 47 disebutkan bahwa perkawinan adalah pemersatuan hati oleh para dewata. Berdasarkan kutipan tersebut di atas, makna perkawinan menurut kitab suci Veda dan susastra Hindu lainnya adalah untuk mewujudkan kebahagiaan bersama lahir dan batin termasuk pula dalam pengertian memperoleh keturunan yang suputra (anak-anak dan cucu-cucu) sebagai penerus kehidupan keluarga. Lebih jauh kitab suci Veda menyatakan bahwa suami istri itu satu jiwa dalam dua badan. $^{23}$

Adapun makna perkawinan dalam agama Budha adalah sebagai hubungan suami-istri untuk memperoleh kesucian (vimakirti sutra). Salah satu pesan moral dari lima aturan (Pancasila Budhis) menjadi pedoman moral setiap umat Budha adalah "Mereka tidak boleh menyalahgunakan seks". ${ }^{24}$ Dalam ajaran Budha diuraikan tugas-tugas yang perlu dilaksanakan oleh suami terhadap istrinya dan juga sebaliknya. Sebagai mana yang disabdakan oleh Sang Buddha dalam Digha Nikaya III, 118, yaitu bahwa tugas suami terhadap istri adalah memuji, tidak merendahkan atau menghina, setia, membiarkan istri mengurus keluarga, memberi pakaian dan perhiasan. Dalam agama Budha kedudukan istri merupakan sahabat tertinggi suami (Samyutta Nikaya 165) ${ }^{25}$.

Mendasarkan pada makna perkawinan dalam berbagai agama yang ada di Indonesia dapat diketahui bahwa perkawinan adalah lembaga suci yang diagungkan dan dilindungi oleh atauran-aturan dalam agama, karena dalam setiap agama menyebutkan bahwa perkawinan bukan hanya ikatan antar manusia akan tetapi dalam suatu perkawinan selalu ada keterlibatan tangan Tuhan. Di samping itu, dalam berbagai agama tersebut dijelaskan bahwa perkawinan adalah lembaga penting dalam kehidupan beribadah maupun dalam bermasyarakat. Masyarakat Indonesia adalah masyarakat religius ${ }^{26}$, bagi masyarakat Indonesia agama adalah petunjuk dan tuntunan hidup serta norma dasar yang menjiwai norma-norma lain dalam hidup bermasyarakat dan dalam menyelenggarakan tata pergaulan masyarakat Indonesia. Oleh sebab itu apabila agama-agama yang menjadi tuntunan hidup masyarakat Indonesia mengagungkan perkawinan dan melindungi kesucian perkawinan, maka demikian pula keyakinan dan sikap masyarakat Indonesia terhadap perkawinan.

${ }^{23}$ Makna Perkawinan dalam Agama Hindu <http://www.parisada.org/index.php?option=com_content\&task =view \&id=502\&Itemid=79\&limit=1\&limitstart=2> diunduh pada hari Senin tanggal 25 November 2013

${ }^{24}$ Makna Perkawinan dalam Berbagai Agama, <http://pormadi.wordpress.com/2008/05/10/makna-perkawinandalam-berbagai-agama/> diunduh pada hari Senin tannggal 25 November 2013

25 Makna Perkawinan dalam Agama Budha, <http://artikelbuddhist.com/2011/05/perkawinan-dalam-agamabuddha.html>, diunduh pada hari Senin tanggal 25 November 2013

${ }^{26}$ Soerojo Wignjodipoero, Pengantar dan Asas-asas Hukum Adat, PT. Gunung Agung, Jakarta, 1968, hlm. 68. Di Indonesia terdapat Sistem Hukum Adat yang bersendi atas dasar alam pikiran bangsa Indonesia, oleh sebab itu untuk memahaminya harus menyelami dasar-dasar alam pikiran yang hidup di dalam masyarakat Indonesia. Adapun salah satu corak hukum adat adalah religio-magis yang berhubungan dengan pandangan hidup alam Indonesia. Berdasarkaan penjelasan tersebut maka dapat dikatakan masyarakat Indonesia adalah masyarakat yang religius. 
Lembaga perkawinan adalah lembaga suci yang harus dihormati dan dijaga kesuciannya. Oleh sebab itu apa bila ada pihak-pihak yang mengganggu keberadaan lembaga perkawinan dan menodai kesuciannya, maka yang tidak menerimakan bukan hanya individu yang menjadi korban, akan tetapi seluruh masyarakat yang terkait, bahkan masyarakat ikut bertanggung jawab untuk mengembalikan kehormatan dan kesucian lembaga perkawinan dengan cara memberikan sanksi pada siapa saja yang telah merusak lembaga perkawinan tersebut. Keikutsertaan seluruh masyarakat dalam mensikapi terjadinya penodaan lembaga perkawinan dapat dipahami karena setiap tahapan dalam proses perkawinan masyarakat tidak hanya melibatkan dan menjadi tanggung jawab individu akan tetapi melibatkan dan menjadi tanggung jawab keluarga dan masyarakat.

Dengan memahami makna perkawinan dan keberadaan lembaga perkawinan bagi masyarakat Indonesia maka dapat dipahami bahwa zina adalah sebagai salah satu bentuk perbuatan yang menodai perkawinan dan merusak sistem kekerabatan. Oleh sebab itu dalam norma agama, delik perzinahan bukan delik aduan melainkan delik biasa karena secara filosofi pelarangan tersebut ditujukan untuk melindungi kehormatan social, karena perkawinan dalam norma agama bukan hanya hubungan atau ikatan antara individu melainkan juga ikatan keluarga bahkan masyarakat atau sosial.

Banyaknya tahapan maupun syarat yang harus dipenuhi dalam melakukan perkawinan berdasarkan norma-norma agama secara filosofi juga menunjukkan bahwa hubungan seksual tidak sekedar melampiaskan nafsu yang secara mudah dapat dilakukan terhadap siiapa saja melainkan suatu perbuatan yang mempunyai tujuan mulia antara lain dalam rangka mendapatkan keturunan. Oleh sebab itu pelarangan zina dalam norma-norma agama ditujukan untuk melindungi nasab atau keturunan dan mensakralkan hubungan seksual.

Berdasarkan landasan filosofi dari pelarangan zina dalam agama-agama yang diakui di Indonesia menunjukkan bahwa perzinahan bukan delik aduan absolut karena nilai-nilai yang dilindungi tidak hanya lembaga perkawinan, melainkan juga melindungi kehormatan sosial serta perlindungan terhadap "social values of sexual morality". Hal inilah yang secara filosofis Pasal 284 KHUP bertentangan dengan Pasal 29 aya (1) UUD 1945.

\section{E. Penutup}

1. Secara yuridis Pasal 284 KUHP tidak konsisten atau bertentangan dengan Pasal 29 ayat (1) UUD 1945, karena batasan pelarangan zina dalam Pasal 284 KUHP hanya melarang perzinahan pada orang yang salah satu atau keduanya terikat tali perkawinan, jenis deliknya aduan absolut dan sanksinya hanya pidana penjara maksimal 9 bulan. Sedangkan dalam norma-norma agama di Indonesia batasan zina yang dilarang tidak hanya pada orang yang sudah terikat tali perkawinan saja, jenis deliknya bukan delik aduan melainkan delik biasa, serta sanksinya tidak hanya pidana pengasingan (pidana penjara) saja.

2. Secara filosofi Pasal 284 KUHP bertentangan dengan Pasal 29 ayat (1) UUD 1945, karena secara filosofi Pasal 284 KUHP hanya memberikan perlindungan pada lembaga 
perkawinan. Sedangkan pelarangan zina dalam norma-norma agama di Indonesia di samping memberi perlindungan pada lembaga perkawinan juga melindungi kesucian hubungan seksual, nasab, kehormatan individu maupun kehormatan sosial. Dapat dikatakan bahwa pelarangan zina dalam noma-norma agama merupakan bentuk perlindungan terhadap kehormatan sosial serta perlindungan terhadap "social values of sexual morality”.

\section{Daftar Pustaka}

Al-Qur'an

Abu Rohmad, Menjaga Etika dan Norma Perkawinan, dalam Suara Merdeka, Selasa 4 Desember 2012.

A. Ubaidillah, dan Abdul Rozak, Demokrasi, Hak Asasi Manusia dan Masyarakat Madani, ICCE UIN Syarif Hidayatullah Jakarta, Jakarta, 2006.

Barda Nawawi Arief, Beberapa Aspek Pengembangan Ilmu Hukum Pidana (Menyongsong Generasi Baru Hukum Pidana Indonesia, Pidato Pengukuhan Guru Besar Fakultas Hukum Undip, Semarang, 25 Juni 1994. , Bunga Rampai Kebijakan Hukum Pidana, Citra Aditya, Bandung, 1996.

, Reformasi Sistem Peradilan (Sistem Penegakan Hukum) di Indonesia, Badan Penerbit Universitas Diponegara, Semarang, 2011.

Hazairin, Demokrasi Pancasila, Bina Aksara, Jakarta, 1985.

H.R.H.The Late Supreme Ptriarch, Prince Vajirananavarorasa, Gihi Patipatti, alih Bahasa: Bhikkhu Jeto, Pati : Vuhara Hettu Ratna Lokha, 1993.

Leden Marpaung, Kejahatan Terhadap Kesusilaan dan Masalah Prevensinya, Sinar Grafika, Jakarta, 2008.

Moh Mahfud MD, Membangun Politik Hukkum Menegakkan Konstitusi, Pustaka LP3ES Indonesia, Jakarta, 2006. , Politik Hukum di Indonesia, Rajawali Pers, Jakarta, 2009.

Neng Djubaedah, Perzinaan dalam Peraturan Perundang-undangan di Indonesia Ditinjau dari Hukum Islam, Kencana Prenada Media Group, Jakarta, 2010.

Oemar Seno Adji, Hukum (Acara) Pidana dalam Prospeksi, cet. Ke-2, Erlangga, Jakarta, 1976.

Pandita S. Widyadharma, Inti Sari Agama Buddha, Yayasan Dana Pendidikan Buddhis Nalanda, Jakarta, 1983. 
Soerojo Wignjodipoero, Pengantar dan Asas-asas Hukum Adat, PT. Gunung Agung, Jakarta, 1968.

Sunaryati Hartono, Politik Hukum Menuju Sistem Hukum Nasional, Alumni, Bandung, 1991

Suteki, Integrasi Hukum dan Masyarakat, Semarang, Pustaka Magister 2007

Zainuddin, Hukum Pidana Islam, Sinar Grafika, Jakarta, 2007

\section{Perundang-undangan :}

Undang-Undang Dasar Negara Republik Indonesia Tahun 1945

Kitab Undang-Undang Hukum Pidana

\section{Internet :}

http://id.wikipedia.org/wiki/Pelacuran_menurut_agama , diakses pada hari Sabtu 21-Juli 2012

Makna Perkawinan dalam Agama Hindu,, <http://www.parisada.org/index.php?option=com_ content \&task=view\&id=502\&Itemid=79\&limit=1\&limitstart=2> diunduh pada hari Senin tanggal 25 November 2013

Makna Perkawinan dalam Agama Budha, <http://artikelbuddhist.com/2011/05/perkawinandalam-agama-buddha. html>, diunduh pada hari Senin tanggal 25 November 2013

Makna Perkawinan dalam Berbagai Agama, <http://pormadi.wordpress. com/2008/05/10/ makna-perkawinan-dalam-berbagai-agama/,> diunduh pada hari Senin tannggal 25 November 2013 